УДК 171

https://orcid.org/0000-0003-3053-0451

\title{
ПОКЛИКАННЯ ТА ЕТИЧНА ВІДПОВІДАЛЬНІСТЬ ЛЮДИНИ: ЗВЕРТАЮЧИСЬ ДО ТЕМИ ІНШОГО У ФІЛОСОФІЇ ЛЕВІНАСА
}

\author{
Є.I. Мулярчук, кандидат філософських наук, старший науковий співробітник \\ Інституту філософії ім. Г.С. Сковороди НАН України
}

У статті розглядаються можливості інтерпретації теми покликання на основі ідей етики Левінаса та його критики гайдеггерівської фундаментальної онтології. Аргументовано можливість розгляду з позиџій філософії Левінаса покликання як загальнолюдської етичної настанови, як заклику до святості, до пробудження людини від зацікавленості власною особою для піклування про благо інших. В аспекті левінасової ідеї нескінченності та трансценденції розкривається мета покликання як спрямування людини до понадособистісних ичілей та цінностей. Обгрунтовано необхідність пошуку шляхів узгодження кониептуальних можливостей етики та онтологї для вирішення практичних проблем етичної мотивації людини, розуміння умов формування особистісних чеснот і розв'язання моральних суперечностей, які виявляються у здійсненні покликання.

Ключові слова: покликання, поклик, самовизначення особистості, ідентичність, відповідальність, конечність, нескінченність, трансценденція,

Актуальність проблеми. У сучасному світі дедалі більш нагальним стає питання про цілі та сталість людського розвитку. Глобалізація, як неминучий процес, викликає конфлікти національних, культурних, особистісних ідентичностей. 3 іншого боку, $є$ проблема розмивання особистісної цілісності людей, здатності на індивідуальному рівні утримувати розуміння мети та ціннісних вимірів власного життя. Тема покликання. яка на перший погляд видається дещо романтичною, у цьому контексті стає важливою. Але інша проблема полягає у тому, що й покликання сучасна людина дедалі більше розуміє як сферу лише іï приватного самовизначення i самореалізації. Брак етичного зважування особистих цілей на терезах, де на противагу покладаються моральні цінності та уявлення про благо, що перевищують цінність приватного життя, може стати критичним для суспільства. Тому аналіз філософських концепцій, на основі яких вибудовуються альтернативи і можливості розвитку етики самобуття та самоактуалізації людини, є важливим. 
Аналіз досліджень та публікацій 3 теми покликання особистості $\epsilon$ завданням окремої роботи. Етика покликання стала предметом студій М. Вебера, зокрема його знаменитої книги «Протестантська етика i дух капіталізму» [3], доповідей «Наука як покликання і професія» («Wissenschaft als Beruf», 1917) та «Політика як покликання і професія» («Politik als Beruf», 1919) [2, с. 644-735]. Спадок Вебера аналізувався багаточисельних розвідках. Із російськомовної літератури це зокрема праці Ю.М. Давидова, П.П. Гайденко, М.І. Левіної, О.С. Бухарова, К.А. Шутової та ін. 3 останніх англомовних досліджень відзначимо статті Т. Евеста та Д. Міллера щодо трансформації цієї концепції і самої ідеї впродовж минулого сторіччя. В українській соціальній науці веберівські студії актуалізовані передусім роботами О.І. Погорілого. У педагогічному аспекті дослідження та публікації сучасних авторів щодо покликання представляють Д. Бігхем, С. Сміт, Д. ВанУстин, Е.А. Колоззі та Л.С. Колоззі, К. Робінсон, М. Тєнева, Д. Джонсон, С. Фаркас, Т. Фолено та інші.

Тема покликання у філософії безперечно має свій якір в «Бутті і часі» та подальших працях М. Гайдеггера, де йдеться про феномен поклику і власне про покликання людини до відкритості буттєвій істині. В критичному відношенні до цього налаштування позиціонована етика Е. Левінаса, дослідження якої багатоманітні. Зокрема, це праці українських і російських вчених А.Б. Ямпольської, В.А. Малахова, Л.М. Карачевцевої, Н.І. Гринчишин, Н.Є. Шолухо, Я.І. Пошина, І.С. Вдовіної, С.В. Воробйової, Б. Е. Губмана, I.M. Зайцева, А.М. Крюкова, Д.У. Орлова та західних дослідників, таких як П. Аттертон, Л. Букерт, А. Вайс, Б. Вальденфельс, Д. Гэйтс, Дж. Драбінскі, К. Кейз, Б. Кроу, Р.Коген, Дж. Ллевелін, М. Леско. А. Пепержак, С. Сендфорд, М. Тойніссен, М. Хайд, Т. Хантер, С. Хедлі, Д.С. Шиффер та ін.

Метою статті є 3’ясувати можливості інтерпретації теми покликання та вирішення моральних колізій у здійсненні покликання на основі ідей етики Левінаса і його критики гайдеггерівської онтології і метафізики само-буття людини. 
Виклад основного матеріалу. 3 позицій філософії М. Гайдеггера можливо вивести онтологічне розуміння покликання людини та, умовно кажучи, «екзистенційну етику буття собою». Натомість, філософія Е. Левінаса спонукає до розгляду покликання власне в етичному сенсі. Французький філософ заперечує цінність налаштування людини на істину іï само-буття та можливість в такий спосіб осягнути мету і сенс людського існування та істину буття в цілому. Як пише Г, Вальденфельс, «Левінас підриває не тільки перспективу цілого, а й повернення до первинного... проголошує відхід не лише від усякого вчення про буття, але й від гайдеггерівського розуміння буття як вербальної «сутності» або «події», здійснюється ж це через посилання на платонівську ідею блага як «надбуттєво націлену»» [1, с. 63].

3 текстів Левінаса можливо сформувати витлумачення покликання як загальнолюдського, такого, що в етичному сенсі однакового стосується всіх. Етичне ставлення до людей - це те, до чого покликана кожна особистість без винятку. Про професійні чи тому подібні виміри індивідуального покликання у Левінаса не йдеться. Натомість обгрунтовується етичний обов'язок відповідати перед іншими людьми. Відповідання на етичний поклик - це «екс-ценденція», вихід людини поза освоєне нею місце у світі та потребу подолати ii власну конечність. Нескінченність, за Левінасом, протилежна тотальності буття. Ї̈̈ можливість полягає у відкритості особистості назустріч іншим, перед якими вона безмежно зобов'язана і чия конечність завжди важливіша за їі власну.

Левінас відмовляється від визнання самодостеменного суб'єкта як відправної точки світовідношення. У розумінні класичної філософії та феноменології самосвідомість суб’єкта $є$ джерелом достеменності його пізнання. Попри те свідомість іншої людини є тотожною або подібною до його власної, і ця тотожність постулюється задля обгрунтування об'єктивності знання і цілісності світу. На думку Левінаса, така позиція хибна. Етичне ставлення до інших і взагалі будь-який досвід людини - це відкриття 
нетотожного їй. Інший у нашому досвіді не є таким, які ми є для себе, його існування становить не теоретичну, а практичну в моральному сенсі проблему.

Левінас тому й відкидає пріоритет бачення, як ідеал пізнання покладений в основу західної цивілізації, оскільки така споглядальна позиція об’єктивує досвід і робить їі суб'єкта невразливим та невідповідальним, таким, що сприймає себе в центрі світу. I в такій настанові феноменологія також цілком відповідає традиції думки, від якої відходить Левінас. У збірці статей до 100-річчя Левінаса, виданої в Санкт-Петербурзі, Д.У. Орлов відзначає, що в якості феноменологів «ми заздалегідь зуміли зробитися невидимими, приховати своє обличчя, конституюватися у формі трансцендентального суб'єкта, який цілком і відразу оглядає поле свого досвіду» [Эмманюэль Левинас, 2006: 90]. I в тексті самого Левінаса читаємо: «Як, слідуючи за Св. Августином, відзначив Гайдеггер, ми користуємося поняттям “бачення” стосовно будь-якого досвіду, навіть якщо в ньому задіяні інші органи чуття. “Схоплювати” знаходиться в такому ж привілейованому становищі. Тут ідея і поняття безпосередньо співпадають 3 досвідом. Подібна інтерпретація досвіду, заснована на баченні і відчуттях, не випадкова і, таким чином, може розвинутися в цивілізацію» [4, с. 195].

Левінас критикує встановлену в такий спосіб ідею тотальності буття, як іманентну, таку що не допускає погляду ззовні: «Бачення - це не трансценденція... Воно не відкриває нічого такого, що за межами Тотожного було б абсолютно іншим, тобто існувало б у собі» [4, с. 197]. Відповідно, він тлумачить ідею світла як вияв думки в парадигмі тотальності буття: «Світло... робить можливим виникнення значень предметів, які дотикаються один до одного. Воно не дозволяє наближатися до них 3 лицевого боку» [4, с. 197]. Тотальність бачення і засліплення світлом закривають можливість пізнати нескінченність. Бачення завжди центроване довкола місця його суб'єкта, що означає «завжди бачити на горизонті», а тобто не могти відкрити щось інше «по той бік всякого буття». Тому воно вдовольняється конечним i залишає без уваги нескінченне. У такий спосіб начебто 
«свідомість повертається до себе», але й себе ми не знаємо, «постійно вислизаючи від себе у баченні» [4, с. 198].

Філософ пише про потребу змінити установку на бачення об'єктів тим світовідношенням, яке кожному відоме у безпосередності людських почуттів, насолоди і страждання, які знезначують об'єктивність світу. У стосунку до іншої людини ми знаходимося до того, як зайняти позицію суб'єкта пізнання. Інший - це обличчя. Обличчя іншої людини не сприймається нами як об’єкт, як предмет відчуттів, якими наповнюються апріорні розсудкові форми. Наш досвід інтерсуб’єктивний, ми знаходимо себе та інших у просторі поміж нами. Первинною є наша відкритість до іншого, а не наша ідентичність та самодостеменність. Левінас пише, що це налаштування на відкритість «відмінне від бачення форм i не може бути вираженим ні в поняттях споглядання, ні в поняттях практики». [4, с. 199].

Йдеться про таку позицію суб'єкта, коли він не є тим, хто править і впорядковує речі у світі. I з цього походить можливість етичної асиметрії людських стосунків. Особистість існує в етичний спосіб, не облаштовуючись у світі, а відповідаючи іншим, і в самому цьому відповіданні долає свою буттєву першість. Інший - це можливість відмовитися від нагальності буття собою і взагалі вивільнитися від думки про буття, адже він не є феноменом. В етичному ставленні ми не шукаємо якоїсь сутності поза зовнішнім виглядом іншої людини. Її обличчя - це моральна вимога до нас. «У розумінні Левінаса, інший пов’язаний перш за все 3 можливістю полишити місце, подолати його тяжіння, розпустити клубок інтенцій... Інший не піддається феноменологічній дескрипції, вимагаючи стосовно себе не опису, а вчинку, - віри, любові, ворожнечі, відповідальності,» - пише Орлов [5, с. 89]. На думку Левінаса, «Інший» є «нескінченно трансцендуючим», «його обличчя, яке свідчить про його богоявленість і звертається до мене, пориває зі світом, який може бути для нас спільним...» [4, с. 199, 200$].$

Філософія Левінаса виходить поза парадигму класичної західної ідеї людини як автономного суб'єкта та їі ідеалу особистої свободи, а отже й веде 
нас поза межі думки про покликання, як такого, в якому людина реалізує себе, здійснює власну місію у світі. «Інший», як категорія Левінаса, вказує на спосіб існування свідомості людини у іï «неминучому відношенні до іншої особи» [6, с. 30]. Людська суб’єктивність надихається інтерсуб’єктивністю вже до і понад своєї уявної єдності та центрованості у собі. Дослідник Левінаса К. Джолдерсма наводить фізичну аналогію вдихання повітря 3 досвідом іншого. Маючи потребу дихати, ми, вільні й автономні суб’єкти, є залежними від іншого і відкритими йому. Ми вбираємо це інше в себе, інакше не можемо існувати. Такою ж є залежність самості від iї апріорного стосунку до іншої людини. «Інший входить в саму серединність суб’єкта..., підважуючи суб'єктивне відчуття самодостатності. До самодостатнього я (I) натхнення (inspiration) виявляє відповідаючого мене (mе)» [6, с. 30]. Стосунок до іншого, як пише Левінас, нівелює уявлення про свідомість. як таку, «промені якої виходять з Я», натомість, «ставить “я” під питання» [4, с. 200]. Присутністю іншої людини ми покликані до етичної відповідальності, яка потребує нас в цілому. Ми стаємо в моральному сенсі заручниками людей, але вже не рабами власних бажань, які закорінювали нас у світі.

Інтерпретуючи те, що філософ писав про мову та спілкування, в термінах поклику, скажемо, що поклик, як і мова взагалі, «приходить до мене від іншого і облаштовується у свідомості», але мова «веде свою гру не всередині свідомості» [4, с. 208]. У спілкуванні ми виходимо поза власні межі, «словесне спілкування успішніше, ніж розуміння, пов’язує нас 3 тим, що залишається по суті своїй трансцендентним». Якщо бачення «пристосовує до себе побачене, інтегрує у світ, наділяє його сенсом», то чуття слова «ставить під сумнів сенс, який я приписую співрозмовнику», «тим самим формальна структура мови проголошує етичну недоторканність Іншого, його “святість”», а «ставлення до іншого вводить вимір трансценденції» [4, с. 199, 200]. Етичний поклик кличе не до тотальності цілого, в якій нам призначене місце і відведений сенс нашому буттю, але у нескінченність зобов'язання перед іншими. Власне, це можна назвати покликанням до святості. У книзі 
«Про Бога, який стає ідеєю» філософ пише, що святість є Третьою особою у стосунку до іншого - «Він в Ти» - «Він не осипає мене благами, але закликає мене до доброти» [5, с. 218],

3 причетності до сфери об’єктивного, природи, суспільства, моралі, політики, буття в цілому пізнається не покликання людини, а її призначення. Такий висновок можливо зробити з гайдеггерівської філософію поклику. Dasein - це і є сама спрямованість до розуміння буття, на онтологічному фундаменті якої екзистенція набуває визначеності свого «хто», стає кимось, впорядковуючи підручні їй речі, зчитуючи з їх розуміння певне до себе звернення, призов брати участь у бутті в цілому. Людина закликана розкривати значення сущого у світі, як пастух буття, вона живе за ідеалом тотожності й тотальності, причетності до того, чому належить бути. Але як конечна людська істота, вона не поєднана з тим, що іiі кличе, зрештою, відповідає лише за себе і залишається собою в жаху одинокості перед смертю. Безперечно, рішучість бути собою до кінця, відкритість, свобода, відповідальність і цілісність людини як екзистенційні чесноти потрібні у покликанні. На цій онтологічній основі можлива визначеність особистості у світі, вибір її справи у житті та здатність йти своїм шляхом - тобто, власне кажучи, всі конкретні вияви покликання. Відповідати на поклик бути собою це прагнути автентичності, шукати і розуміти істину у бутті. Але це служіння призначеному, буттю в істині до кінця, без чуття нескінченного поза ним. Неможливо знайти вихід поза власні онтологічні межі в собі самому, і в тотальності буття немає такого виходу.

На противагу ідеї причетності та призначення людини до розкриття сенсу буття сущого Левінас пише, що «мета свідомості... полягає не в тому, щоб через представлення дорівнятися до буття, прагнути до світла, у якому виявляється ця тотожність, а в тому, щоб піднятися над цією грою світла цією феноменологією - і давати здійснюватися подіям, вищий сенс яких, всупереч Гайдеггеру, полягає зовсім не у виявленні», але у «прийнятті» іншого (обличчя) і в утвердженні справедливості, «які зумовлюють 
народження самої істини» та «не інтерпретуються як розкриття». Феноменологію Левінас визнає як метод, але не як мету філософії [4, с. 71].

Левінас пропонує розуміння нескінченності в есхатологічній перспективі. Його думка веде поза ідею достеменності та цінності власного місця людини у світі. Філософ пише: «Есхатологічне, як таке що перебуває “по той бік” історії, вириває людей 3 їх підпорядкованості історії та майбутньому - воно закликає, спонукає їх до повноти відповідальності» [4, с. 68]. Така етично-есхатологічна відповідальність можлива, якщо розглядати суб’єктивність «не в плані їі суто егоїстичного протесту проти тотальності i не у ї тривозі перед лицем смерті, але як таку, що коріниться в ідеї нескінченного» $[4$, с. 70]. Етичний поклик до відповідальності перед Іншим переважає нас самих. Він проходить «через нас» і спрямовує на благо вище, ніж наше буття. Левінас пише, що «ідея нескінченного передбачає ідею душі, здатної утримати в собі більше, ніж те, що вона може взяти із самої себе» [4, c. 191]. Поклик не є просто феноменом свідомості, це безпосереднє зобов’язання перед іншою людиною, перед їі буттям.

Інтерпретуючи філософію Левінаса в термінах нашого дослідження, сформулюємо таке визначення: етичне ставлення до іншого - це і $\epsilon$ покликання людини, а поклик - це спонукання до такого ставлення. «Бути уважним означає надлишок совісті, що передбачає поклик Іншого», - пише сам Левінас [4, с. 189]. Поклик не є лише одиничним, первинним спонуканням, про яке пригадують. Натомість, він звучить, «постійно відновлюючись», «являючись 3 обличчя» іншого [6, с. 58]. Сама присутність іншого, його обличчя $\epsilon$ «заклик і навчання, входження у стосунок до «я»- етичне ставлення» [4, с. 192]. Етичне зобов'язання перед іншою людиною дієве, коли його чують і розуміють як поклик, інакше воно стороннє, до нас не звернене, таке, що нас не торкає.

В практичному сенсі, ми покликані бути для інших. Етика покликання в сенсі конкретного продумування норм та цінностей людського існування не буде чимось надто специфічним, порівняно, наприклад, iз професійною 
етикою. Тому іiі предметом передусім має бути етос покликання, спосіб людини бути у покликанні та ставлення до інших людей в контексті здійснення їхнього покликання. Ї̈̈ основними мотивами будуть свобода та відповідальність особистості. Відповідальність перед іншими, як про неї пише Левінас, зачіпає свободу само-буття особистості, як свободу «від чогось», і вимагає етичного, на противагу суто екзистенційному, розуміння свободи бути «для когось». Етичний поклик, що йде від іншого, цю свободу пробуджує. «Людина виражає себе, заявляє про себе, закликаючи до мене всією своєю злиденністю та незахищеністю, голодом, і робить це таким чином, що я не можу не відгукнутися на її поклик. Так... істота, яка заявляє про себе, не обмежує мою свободу, а, навпаки, пробуджує іï, викликаючи у мені доброту». [4, с. 205]. Цей поклик веде до більш повної реалізації людиною себе у світі, адже розмикає іiі. У спілкуванні з іншою людиною, яка звернена до нас своїм обличчям, «першим словом виявляється зобов'язання, від якого не дає змоги ухилитися ніяке “внутрішне”» [4, с. 205]. I цим не спростовується свобода, вона вимагається. Інший - не господар стосовно нас, він $є$ земним, «співмірним до того, хто його приймає», і тому його обличчя, «замість того, щоб обмежувати мою свободу, воно ії закликає до відповідальності», - пише Левінас [4, с. 207].

Ми покликанні до буття іншими, ніж ми самі. Взагалі, в існуванні кожного сущого є своя містика його генези від іншого, адже «воно $є$ тим, чим $€$, не зі своєї власної внутрішньої динаміки, але тому що воно покликане до буття звідкись, ззовні себе» [6, с. 12]. Левінас пише про цю таїну «Іншого» як такого, який «приходить до нас ззовні, як окреме - або святе - обличчя. Його екстеріорність - тобто його поклик, звернений до мене, - це його істина. Моя відповідь ... лише виявляє його істину (яку його “точка зору” на мене не може зняти). Ця надлишковість стосовно буття і до ідеї буття, яку ми позначаємо за допомогою метафори “викривлення інтерсуб’єктивного простору” означає божественну інтенцію всякої істини. Це “викривлення простору” є, можливо, сама присутність Бога» [4, с. 274]. Таким чином, 
істина не феноменальна і не розкривається у пізнанні. Вона - у самій нашій відповідальності на поклик Іншого, «вона - буття, яке знаходиться в сфері суб'єктивного, яка деформує бачення, але дає тим самим можливість наказовій, владній екстеріорності заявити про себе, про свою повну перевагу» [4, с. 273].

Наголосимо насамкінець ще раз на суперечності цінності буття собою, обгрунтованої Гайдеггером, та відповідальності перед іншим, згідно думки Левінаса, у контексті етики покликання. Відзначимо, що у Гайдеггера сфера поклику - це спочатку світ повсякденності, роботи з «підручним» сущим, але достеменність опанування цього світу підважується смертю, перед якою Dasein pішуче намагається вирватися до автентичного буття собою. Згодом думка філософа веде до поклику від самого буття в цілому, його відкритості людина служить, здійснюючи його істину. Однак у такому розумінні вона стає лише провідником цього поклику, тим хто його чує і розуміє. 3 погляду ж Левінаса, саме буття не кличе, у ньому немає напрямку і виходу без присутності іншої людини, без Бога виявленого у ії обличчі. Інший стає для нас покликом зробити крок у позамежне, відкритися нескінченному. Ми не стурбовані тим, як зрозуміти його поклик. Ми вже покликані в сенсі безконечної відповідальності перед Іншим як людиною або Богом. Дійсність поклику виявлена у цьому нашому відповіданні i в провині за безвідповідальність.

На відміну від Гайдеггера, який розкривав спосіб існування людини як iii бажання буттєвої істини, Левінас пише про первинне бажання і вимогу добра від людини. «Доброта як абсолютна, не прорахована пригода є сама трансценденція. Трансценденція - це трансценденція “я”. Тільки “я” здатне відповісти на той наказ, що виходить від обличчя» [4, с. 285, 286]. Земне «я» людини закликане Іншим не до вічності, але до нескінченності в сенсі безперервності іiі відповідання [4, с. 161]. Підсумовуючи свою позицію стосовно філософії Гайдеггера, Левінас відзначає: «Отже, ми вважаємо, що порвали з філософією Нейтрального - 3 гайдеггерівським буттям сущого...», 
тобто 3 буттям, «Логос» якого є «нічиїм словом» [4, с. 280]. Натомість. «виходити $з$ обличчя як джерела, в якому народжуються всі смисли... означає стверджувати, що буття здійснює себе у відносинах між людьми, що Бажання керує вчинками радше, ніж потреба. Бажання - прагнення, що виникає не з нестачі, метафізичне, - бажання особистості» [4, с. 280].

Висновки і перспективи подальших досліджень. Таким чином, слідуючи за думкою згаданих філософів, ми проходимо шлях формування етичного уявлення про покликання - від зобов'язання людини бути собою до кінця, реалізувати себе, до ідеї про первинність етичного обов'язку до відповідальності перед іншими, в якій виявляється єдино можлива для неї нескінченність. Відзначимо, що з обох позицій складно увійти до реальності практичного здійснення покликання у конкретних життєвих справах та в служінні людям довкола нас. Дійсність покликання людини осягається поміж крайнощами стурбованого собою само-буття та беззастережної відданості і відповідальності перед іншими, в яких людина забуває саму себе. Натомість, більш практично орієнтованою була б етика, яка розташовує людину в іiі місцезнаходженні у світі, визнаючи водночас і турботу про істину їі буття i піклування про можливості їі співіснування з іншими у світі. У подальших дослідженнях варто шукати можливості узгодження етики з онтологією, аналізуючи умови формування особистісних чеснот і моральні суперечності, які неминуче виявляються у здійсненні покликання.

Список використаних джерел

1. Вальденфельс Б. Вступ до феноменології. - К.: Альтерпрес, 2002. - 173 с.

2. Вебер М. Избранные произведения. - М.: Прогресс, 1990. - 808 с.

3. Вебер М. Протестантська етика і дух капіталізму / Перекл. 3 німецької О .Погорілого. - К.: Основи, 1994. - $261 \mathrm{c}$.

4. Левинас Э. Избранное. Тотальность и бесконечное. - М.; СПб: Университетская книга, 2000. - 415 с.

5. Эмманюэль Левинас: Путь к Другому. Сборник статей и переводов, посвящённый 100-летию со дня рождения Э.Левинаса. - СПб.: Издательство СПбГУ, 2006. - 236 с.

6. Joldersma C. A Levinasian Ethics for Education's Commonplaces: Between Calling and Inspiration. N.Y.: Palgrave MacMillan, 2014. - 126 p.

\section{References}

1. Waldenfels B. Introduction to Phenomenology. - K.: Alterpres, 2002. - 173 c. (in Ukrainian).

2. Weber M. Selected works. - M.: Progress, 1990. - 808 p. (in Russian).

3. Weber M. The Protestant Ethics and the Spirit of Capitalism / Tr. from German O. Pohorilyi. - K. Osnovy, 1994. - 261 p. (in Ukrainian). 
4. Levinas E. Selected works. Totality and Infinity. - M.; SPb: Universitetskaya kniga, 2000. - 415 p. (in Russian).

5. Emmanuel Levinas: The way to the Other. Selection of articles and translations, devoted to100-anniversary of E.Levinas. - SPb.: Publishihing of SPbSU, 2006. - 236 p. (in Russian).

6. Joldersma C. A Levinasian Ethics for Education's Commonplaces: Between Calling and Inspiration. N.Y.: Palgrave MacMillan, 2014. - 126 p.

\title{
ПРИЗВАНИЕ И ЭТИЧЕСКАЯ ОТВЕТСТВЕННОСТЬ ЧЕЛОВЕКА: ОБРАЩАЯСЬ К ТЕМЕ ДРУГОГО В ФИЛОСОФИИ ЛЕВИНАСА
}

\author{
Е.И. Мулярчук
}

В статье рассматриваются возможности интерпретации темы призвания на основе идей этики Левинаса и его критики хайдеггеровской фундаментальной онтологии. Аргументирована возможность рассмотрения с позиций философии Левинаса призвания как общечеловеческой этической установки в качестве призыва к святости, пробуждения человека от заинтересованности собой для заботы о благе других. В аспекте левинасовской идеи бесконечности и трансценденции раскрывается цель призвания как направленности человека к сверхличностным целям и ценностям. Обоснована необходимость поиска путей согласования концептуальных возможностей этики и онтологии для решения практических проблем этической мотивации человека, понимания условий формирования личностных добродетелей и решения этических противоречий, которые проявляются в осуществлении призвания.

Ключевые слова: призвание, зов, самоопределение личности, идентичность, ответственность, конечноість, бесконечность, трансценденция.

\section{CALLING AND ETHICAL RESPONSIBILITY OF A PERSON: APPROACHING TO THE THEME OF THE OTHER IN THE LEVINASIAN PHILOSOPHY}

\section{Y.I. Muliarchuk}

The task of the research is to determine the possibilities of interpretation of the theme of calling on the basis of the ideas of the ethics of E. Levinas and his criticism of Heideggerian fundamental ontology. Following the main positions of Levinasian philosophy the author of the article proves the relevance of the understanding of calling as a common to mankind direction and requirement of holiness and awakening from interestedness in oneself to concern for the other people's welfare and good. On the basis of Levinasian ideas of infinity and transcendence the purpose of calling reveals itself in devotion of person's aims and values to over-personal aims and values.

The phenomenon of call reveals itself not as the claim of authenticity of self-being and towards the truth of being as a whole, but as a need to answer to the Other. Not a Heideggerian fear and resoluteness of finiteness found the values in human life, but the infinity of living for the other people. The study follows the thought of Levinas that infinity reveals itself in the person and makes the person able to overcome anxiety of own death and overcome the limits of living towards it. The study examines the criticism by Levinas of phenomenological attitude to rely upon the self-certainty of subjectivity and his positioning of the certainty of ethical obligation based on the intersubjective experience and the requirement of responsibility towards the other people.

The research determines the necessity of the search of the ways for harmonization in the concept of calling of the positions of ontology and ethics. Therefore the author foresees the possibility for solution of practical problems concerning ethical motivation of personality, of general understanding of the conditions for forming of personal virtues, of answering the various calls of living in the world, and of solving the collisions revealed in the realization of personal understanding of calling.

Key words: calling, call, покликання, поклик, self-determination of personality, identity, responsibility, finiteness, infinity, transcendence. 